\title{
Southern Pizza, Inc.: The Case Of An Innovative Franchisee
}

Tará Burnthorne Lopez, Southeastern Louisiana University, USA

\begin{abstract}
Consuming more than 350 slices per second, Americans have made pizza one of their favorite fast foods. It is a rare town that does not boast at least one pizza outlet. Indeed, pizza can be purchased in bowling alleys and service stations, at sporting events, in theaters, as well as at national and local pizza restaurants located throughout the United States. This paper presents case material on a major pizza franchisee, its operations and its goals. Material presented can be useful in teaching marketing strategy.
\end{abstract}

Keywords: Pizza industry, marketing strategy, segmentation

\section{INTRODUCTION}

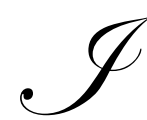

magine selling a product that Americans consume at a rate of $350^{1}$ units per second. Pizza has become a staple for teenagers and college students and a convenient backup meal for busy parents resulting in the approximately 3 billion pizzas purchased every year. The industry is dominated by four national pizza chains: Pizza Hut, Domino's, Papa Johns, and Little Caesar's. As number two in the industry, Domino's Pizza has over 7,000 restaurants worldwide and claimed $12 \%$ overall market share and $28 \%$ of the U.S. pizza delivery market in 1999. The company boasts annual revenues of approximately $\$ 3.4$ billion. It's difficult to imagine that Domino's delivered 400 million pizzas in 2001 and in doing so its drivers covered 9 million miles per week!

2002 was a banner year for the pizza chain. They had great new product success with the introduction of Buffalo Chicken Kickers and Domino's Dots. They also demonstrated an understanding of the impulsive nature of pizza sales with their "Get the door, it's Domino's" ad campaign.

In 2004, Domino's Pizza Inc. decided to take the privately held company public. While the predictions about Domino's IPO were favorable, the stock price failed to achieve expectations. On the day of the IPO, the stock price closed at $\$ 13$ per share which was a dollar less than the opening price. One observer blamed the lackluster stock performance on mediocre marketing, citing a lack of new products, a lack of responsiveness to new trends, and meager spending on advertising in the year or so before the IPO' ${ }^{2}$. Essentially, Domino's had failed to extend the momentum they built in 2002 .

\section{ABOUT SOUTHERN PIZZA, INC.}

Southern Pizza, Inc. (Southern) is the largest franchisee of Domino's Pizza. The company is privately owned and family-run out of its headquarters in Gulfport, Mississippi. At one point in the early 1990's Southern owned and operated over 370 Domino's Pizza stores located in Mississippi, Louisiana, New York, Detroit, Michigan, Canada, West Germany, and Chicago. Poor economic conditions and problems associated with longdistance management led Southern to decide to re-focus on its core Mississippi and Louisiana markets. Therefore, Southern sold or closed its stores in other markets and now currently owns and manages 161 stores in Mississippi

\footnotetext{
${ }^{1}$ Americans consume 350 slices of pizza per second.

${ }^{2}$ Marketing malaise, lack of new products cool Domino's IPO, By: MacArthur, Kate, Crain's Detroit Business, 8/16/2004, Vol. 20 , Issue 33 .
} 
(50), Louisiana (104), Alabama (5), and Arkansas (2). The decision to re-focus has proven to be a profitable one. In 2000, revenues were $\$ 100.2$ million with pre-tax profits of $\$ 6.5$ million.

Southern Pizza, Inc. is a highly progressive franchisee. The owners work to create an innovative, open atmosphere. They are constantly seeking ideas for new products, management practices, and marketing strategies. In their continued effort to be a learning organization, Southern is actively seeking the Malcolm Baldridge Award and devised a 5-year plan toward that goal. Southern hopes to be the first pizza restaurateur to achieve this honor. The process of seeking the Malcolm Baldridge Award requires a great commitment among the management and employees of any organization. It requires organizations to examine how they do business from the smallest details to the broadest executive decision processes.

Southern also has a continuous improvement process that is guided by what it calls Continuous Improvement Teams (CITs). CITs are asked to examine the key processes within the company and suggest areas for improvement. Perhaps Southern's openness to examining the way they do business through programs such as the Baldridge Award application and their use of CIT's is one explanation for their continued success in this highly competitive industry.

\section{CURRENT STATUS}

Customer Segments. Southern segments its customers by several variables: delivery/carry-out, residential characteristics, time-of-day purchases, and frequency of purchase. The following chart summarizes Southern's customer segments by delivery/carry-out and residential characteristics.

\begin{tabular}{|c|c|c|c|c|}
\hline $\begin{array}{l}\text { Key Requirements } \\
\text { by Segment }\end{array}$ & $\begin{array}{l}\text { Delivery } \\
(34 \%)\end{array}$ & $\begin{array}{l}\text { Carry-Out } \\
(62 \%)\end{array}$ & $\begin{array}{l}\text { Catering/ Special Events } \\
(2 \%)\end{array}$ & $\begin{array}{l}\text { School Lunch } \\
(2 \%)\end{array}$ \\
\hline $\begin{array}{l}\text { Residential High } \\
\text { Income }\end{array}$ & $\begin{array}{l}\text { High quality } \\
\text { On-time } \\
\text { Clean image }\end{array}$ & $\begin{array}{l}\text { High Quality } \\
\text { Easy, safe store } \\
\text { Clean image }\end{array}$ & \multirow{4}{*}{$\begin{array}{l}\text { Off-site capabilities } \\
\text { Special packaging } \\
\text { Product hold time } \\
\text { Relationship } \\
\text { building }\end{array}$} & \multirow[t]{4}{*}{$\begin{array}{l}\text { Low price } \\
\text { On-time } \\
\text { Relationship building }\end{array}$} \\
\hline $\begin{array}{l}\text { Residential Low } \\
\text { Income }\end{array}$ & $\begin{array}{l}\text { Low price } \\
\text { Promotions } 1^{\text {st }} \text { of month }\end{array}$ & $\begin{array}{l}\text { Low Price } \\
\text { Promotions } 1^{\text {st }} \text { of } \\
\text { month } \\
\text { Easy, safe store }\end{array}$ & & \\
\hline Military & $\begin{array}{l}\text { Special advertising } \\
\text { Smaller packaging } \\
\text { Value price }\end{array}$ & $\begin{array}{l}\text { Special advertising } \\
\text { Smaller packaging } \\
\text { Value price }\end{array}$ & & \\
\hline Campus & $\begin{array}{l}\text { Price } \\
\text { Smaller packaging } \\
\text { Campus affiliation }\end{array}$ & $\begin{array}{l}\text { Low price } \\
\text { Smaller packaging } \\
\text { Campus affiliation }\end{array}$ & & \\
\hline
\end{tabular}

Another variable Southern uses to segment its customers is time-of-day purchases. Lunch customers account for $22 \%$ of sales, dinner for $65 \%$ of sales, and late-night for $15 \%$ of sales. Finally, value can also be obtained from examining customers on the basis of frequency of purchase. Southern identifies four frequency of purchase categories including heavy users, medium users, light users, and new customers.

Competition. Nationally, Domino's Pizza ranks a strong second among the four national pizza chains. Pizza Hut has held the top position for over 20 years. Little Caesar's held the third spot for some time but has been displaced by the rapidly expanding Papa Johns. On the local level, Southern faces these competitors in all of its markets. Furthermore, Southern's markets tend to follow the same trends as the other markets in the U.S.

The following table summarizes the Domino's market share in each of Southern's DMA's. 


\section{MARKET SHARE BY DMA}

\begin{tabular}{|c|c|c|c|c|c|c|c|c|}
\hline New Orleans, LA & Domino's & $42.8 \%$ & Pizza Hut & $30.2 \%$ & Papa John's & $21.1 \%$ & CiCi's & $3.9 \%$ \\
\hline Biloxi, MS & Domino's & 38.8 & Pizza Hut & 38.5 & \begin{tabular}{|l|} 
Papa John's \\
\end{tabular} & 14.1 & Chuck E. & 3.8 \\
\hline Lake Charles, LA & Domino's & 36.0 & Pizza Hut & 35.4 & Mr. Gattie's & 10.9 & Little Caesar's & 9.2 \\
\hline Baton Rouge, LA & Pizza Hut & 41.8 & Domino's & 29.7 & Papa John's & 19.1 & Mr. Gattie's & 5.4 \\
\hline Hattiesburg, MS & Pizza Hut & 46.4 & Domino's & 27.3 & \begin{tabular}{|l|} 
Pizza Inn \\
\end{tabular} & 7.7 & CiCi's & 5.9 \\
\hline Lafayette, LA & Pizza Hut & 37.6 & Domino's & 25.1 & Mr. Gattie's & 16.8 & Papa John's & 7.6 \\
\hline Shreveport, LA & Pizza Hut & 39.2 & Domino's & 23.7 & \begin{tabular}{|l|} 
Johnny's \\
\end{tabular} & 18.0 & Papa John's & 6.0 \\
\hline Meridian, MS & Pizza Hut & 53.3 & Domino's & 20.3 & \begin{tabular}{|l|} 
Papa John's \\
\end{tabular} & 14.0 & Little Caesar's & 6.3 \\
\hline Jackson, LA & Pizza Hut & 41.5 & Domino's & 19.4 & Mazzio’s & 15.2 & Pizza Inn & 7.6 \\
\hline Alexandria, LA & Pizza Hut & 41.4 & Domino's & 16.4 & Chuck E. & 13.2 & Papa John's & 12.6 \\
\hline Columbus, MS & Pizza Hut & 65.6 & Domino's & 11.4 & \begin{tabular}{|l|} 
Papa John's \\
\end{tabular} & 11.0 & CiCi's & 4.8 \\
\hline Monroe, LA & \begin{tabular}{|l|} 
Johnny's \\
\end{tabular} & 38.0 & Pizza Hut & 33.4 & \begin{tabular}{|l|} 
Domino's \\
\end{tabular} & 10.7 & Pizza Inn & 9.2 \\
\hline Greenwood, MS & Pizza Hut & 44.0 & Pizza Inn & 27.8 & Papa John's & 10.8 & Domino's & 10.1 \\
\hline Total & Pizza Hut & 41.0 & Domino's & 29.2 & Papa John's & 12.8 & Johnny's & 4.6 \\
\hline
\end{tabular}

Southern actively watches for new, upcoming competition. In fact, the company is currently keeping its eye on a new entrant into the pizza industry Donato's. While Donato's has not entered the Mississippi/Louisiana market yet, the company has shown great promise and is growing rapidly in other areas of the country. Southern recognizes that competitors come from outside the pizza industry as well. Thus, they scan many other food categories such as hamburgers, chicken, Mexican, and grocery items such as frozen pizzas.

Products and Services. Southern focuses on two segments of the pizza market: delivery and carry-out. Southern management feels that they are capitalizing on their distinctive competencies by focusing on these two segments. While all locations offer delivery and in-store carry-out, approximately 55\% of Southern's stores have drive-thru windows for carry out customers. The other two segments of the pizza industry, dine-in and frozen pizza, require different management and employee skills that Southern believes would not be profitable enough to develop at this stage. Southern has attempted to open dine-in versions of its Domino's stores in the past but they were unsuccessful.

Domino's franchisees are required to purchase goods from approved suppliers. Southern purchases its pizza dough and other food and paper products from Domino's National Commissary System (DNC). Southern has a contract with DNC that includes profit sharing. Quality and consistency is closely monitored by DNC.

Southern defines their operational process to include order taking, pizza preparation, cooking, boxing, and delivery. Their goal is to complete the pizza production process in ten minutes or less to allow for safe delivery of the pizza within the promised timeframe. Customers have a choice of 12" medium or 14" large pizzas made with either a hand-tossed, thin, or deep-dish crust. A variety of pizza toppings are also offered: including pepperoni, smoked ham, ground beef, sizzling bacon, italian sausage, fresh onions, green peppers, black olives, fiery jalapeños, mushrooms, pineapple, cheddar cheese, and extra cheese. While the focus is pizza, Domino's also produces and delivers buffalo wings, buffalo Chicken Kickers, breadsticks, cheesy bread, cinnamon sticks, and soft drinks. They also offer salads in some markets.

Distribution. Southern owns and operates Domino's Pizza locations in Louisiana, Mississippi, Alabama, and Arkansas. Ordering products can be done via telephone or the internet. Southern distributes products through several types of facilities including free-standing stores that offer delivery and carry-out (some of which have drivethru) service and c- stores (convenience stores with a Domino's location attached) that offer delivery and carry-out.

Opening a new store costs between $\$ 118,350$ and $\$ 440,100$ depending on real estate costs in the area and whether the new store is a free-standing facility or an attached facility, such as a c-store. 
Promotion. On the national level Domino's uses mass media advertising and sales promotion to support its franchisees. The corporate office introduced the "Get the door it's Domino's" ad campaign based on the philosophy that pizza is an impulse purchase. In 2003, Domino's Pizza joined the ranks of NASCAR by sponsoring the \#15 Napa car driven by Michael Waltrip. Although Domino's Pizza Inc. spends between \$112 and \$123 million annually on advertising, the company also encourages its franchisees to develop local campaigns to bridge gaps in national advertising.

Within their market, Southern's promotional strategy is based on a philosophy that it describes as "owning days of the week." Southern feels that pizza buying is largely promotion, rather than loyalty, driven. Therefore, the company identifies particular days of the week and bombards various media with ads featuring specials and coupons with the goal of dominating delivery sales on those days of the week. Common sales promotions are free cinnasticks or cheesybread with the purchase of a pizza or "2 for Tuesdays" in which the customer gets two pizzas for the price of one.

\section{CHALLENGE}

For the future, Southern has three goals:

1. Move Domino's Pizza to number one in all markets that Southern serves.

2. Dominate summer sales in college markets. Some markets have large colleges that greatly impact pizza sales. These DMA's include Hattiesburg, and Lafayette. Each of these markets experiences a drop in sales in the summer due to shrinkage of the college customer base.

3. Become a stronger competitor in inner-city markets. Some markets have a large inner-city customer base that may have special needs requiring a specially targeted marketing strategy. These markets include Jackson and New Orleans.

\section{CONCLUSION}

For class use, a variety of discussion questions come to mind. Faculty wishing to instill in students the complexities of marketing strategy may wish to broach the following:

1. What factors in the external environment will impact Southern in the near term? Are there factors that impact all of Domino's markets including those of Southern? Are there factors that are unique to Southern's markets?

2. Which of Southern's three goals is most important and why?

3. Select one or more of Southern's goals and: a) develop appropriate short-term and long-term objectives, and b) develop a marketing program to achieve those objectives. Note: instructor may wish to focus on one or two markets.

4. Using population figures from library resources conduct an analysis of Southern's current locations in each market. Are there missed opportunities? Based on population distribution, does each location appear appropriate? Note: current locations can be obtained from a yellow pages search or from www.dominos.com.

5. Based on the secondary research you've done on the pizza industry and its consumers, what do you feel about Southern's belief that pizza buying is promotion rather than loyalty driven? Create a plan to increase customer loyalty.

6. If you live in an area in which a Domino's pizza is located, develop a primary research plan and collect data from consumers in your area to determine consumer awareness and perceptions of Domino's pizza. If you do not live in an area in which a Domino's pizza is located, develop a primary research plan and collect data from consumers in your area about their awareness of Domino's pizza as well as their satisfaction with the offerings in your area to determine whether or not there is a market for a Domino's pizza location. 
The fast food industry in the United States has witnessed many failures and many successes. Pizza is one of the stronger markets for fast foods. Marketing students can learn much from studying firms like Southern that have moved decisively in their markets to make an impact and achieve market dominance.

Note: Southern Pizza is a pseudonym for a real company.

\section{AUTHOR INFORMATION}

Tará Burnthorne Lopez is an Assistant Professor of Marketing at Southeastern Louisiana University. She has published in the Journal of Business Research, Journal of Personal Selling and Sales Management, the Journal of Marketing Education, and the Journal of Marketing Theory and Practice, among others, and has had papers accepted at several national and regional conferences. Tará completed her doctoral work at Louisiana Tech University and has held also positions at University of Southern Mississippi and Mississippi College.

\section{NOTES}


NOTES 